\title{
The Case for Teaching Culture through Neglected Authors: Carmen de Burgos and the Generation of ' $98^{1}$
}

Sally W. Thornton ${ }^{2}$

Indiana University of Pennsylvania

\section{RESUMEN}

Teóricos del campo de la lingüística aplicada sostienen que para estudiantes de segunda lengua. la adquisición de la competencia cultural mejora por el uso de obras literarias. Aquí se propone que al integrar en la clase autores olvidados o marginados se ponen de relieve las ambigüedades, diferencias y contrastes presentes en la cultura predominante. Se ilustra cómo, en dos cuentos cortos de Carmen de Burgos. se plantea el problema de la mujer con todo lo complejo del tema. asunto casi pasado por alto por los autores incluidos en la Generación del ’98.

\section{Abstract}

Applied linguistics theorists maintain that the acquisition of cultural competence by second-language students is enhanced through the use of literary works. The proposition of the present article is that by incorporating neglected or marginal authors in the classroom, the ambiguities, differences and contrasts present in the predominant culture are highlighted. Through the study of two short stories by Carmen de Burgos, the woman question, a subject largely ignored by the Generation of 1898 writers, is set out in all of its complexity.

\footnotetext{
I Ponencia presentada en el I Congreso Internacional de Lingiiística Aplicada. llevado a cabo en octubre de 2007, en el Campus Omar Dengo. de la Universidad Nacional de Costa Rica.

2Correo electrónico: swthom@iup.edu
} 
Palabras clave: Lingüística aplicada, competencia cultural, narrativa española, Generación del '98

Keywords: Applied Linguistics, cultural competence, Spanish narrative, Generation del 1898

"try and catch the colour of life itself"

Henry James, The Art of Fiction

London: Macmillan, 1899

Facilitating the acquisition of cultural competence in the traditional second language classroom of ten becomes tedious and routine, because if differing cultural practices and patterns are merely explained but not illustrated, students have difficulty grasping culture's "constantly shifting". and of ten ambiguous nature. However, cultural awareness can be a pleasant and productive pursuit when linked to literature. and this can be just as true for elements traditionally omitted from the teaching of cultural norms. We can tell students that the perspective of women has often been at odds with and omitted from our store of cultural knowledge, or we can show it through the reading of literary works by women. While students read works of literature, they come to appreciate that ambiguity, differences and disagreements about cultural norms are common from within as well as from without. In this case, the use of the short story is the ideal medium, because there is rarely time in a class emphasizing culture to study more extensive works. Selecting stories from neglected or marginal authors can bring cultural contrasts, complexities and omissions to the foref ront of class discussions.

Various theorists in the field of pedagogy have discerned the value of literature as a tool for teaching culture. Claire Kramsch in her

Jean Marie Schultz, "The Gordian Knot: Language, Literature. and Critical Thinking.” AAUSC I.ssues in Language Program Direction. Eds. V. M. Scott and H. Tucker (Boston: Heinle \& Heinle. 2001) 14 . 
study of culture and classroom content writes that: "...the main argument for using literary texts in the language classroom is literature's ability to represent the particular voice of a writer among the many voices of his or her community and thus appeal to the particular in the reader." 4 She also writes of the "cultural imagination" of a society that is as real as are the history and products. ${ }^{5}$ Janet Swaffer stresses the reader's task in detecting the patterns in written texts that reveal information about particular cultural values, behavior and attitudes. ${ }^{6}$ Virginia Scott and Julie Huntington have shown that "literary texts contribute to students' affective awareness and cognitive flexibility. ${ }^{7}$ Thus, there are valid and compelling pedagogic reasons for employing literature in the classroom as a useful tool for teaching culture and as a stimulating approach to the subject.

However, that curriculum of ferings in literature tend to perpetuate the same canon of authors reflects the inertia that of ten accompanies the profession and is a significant consideration vis à vis the presentation of cultural content. Nowhere is this more evident than in the traditional selection of Spain's Generation of 1898 authors. Though it is always emphasized that these turn of the century writers were preoccupied with the "problem" of Spain, that the woman question was a part of this problem and polemic is virtually omitted from the discussion. For the male authors of this generation of writers, it was of peripheral concern. Yet Michael Ugarte reminds us that it was Unamuno of the Generation of '98 who penned the term "intrahistoria," and that there is perhaps no one of that time period who more conveys this sense of absence from recorded history yet physical presence than Carmen de Burgos "who writes Spanish women's 'intrahistoria' most articulately and

\footnotetext{
4 Claire Kramsch. "Teaching the Literary Text." Context and Culture in Language Teaching. 6th ed. (Oxford: Oxford UP. 2004) 130-131.

Kramsch, 207.

- J. Swaffer, "Written Texts and Cultural Readings." Text and Context: Cross Disciplinan Perspectives on Language Study. Eds. C. Kramsch and S. McConnell-Ginet (Lexington. MA: D.C. Heath, 1992) 242.

7 Virginia M. Scott and Julie A. Huntington, "Reading Culture: Using Literature to Develop C2 Competence." Foreign Language Annals 35.6 (2002): 622.
} 
elaborately." 8 The major aesthetic trend of the era of the Generation of '98 authors was, of course, modernism, which Roberta Johnson characterizes as "a particularly masculine movement" where "modernist women were out of place" because "[l]iterary modernism emphasized form and philosophy over social phenomena such as women's shifting roles in the modern world" and emphasizes "the masculine subjective experience of the world." She wrote of Burgos in relation to the noventayochistas (Generación del '98) and novecentistas (Generación del '14) that: "Her social modernism, especially within the context of contemporaneous Spanish society and literature, flies in the face of tradition and deserves a place alongside the[ir] modernisms" [emphasis mine]. ${ }^{10}$

While no critic has included a single woman as pertaining integrally to this admittedly loosely related grouping of writers born between 1867 and 1875 (Generation of 1898), recently several critics have mentioned this omission. ${ }^{11}$ In fact, Ugarte himself has written that Burgos is rather marginal: "We find a need to include the works of Burgos in the canon of Spanish literature, but they do not seem to fit.... Her concerns, and the styles and genres in which she chooses to express them, are different." "However, whereas many critics contend that any concept of a unified Generation of ' 98 authors is impossible to maintain because the individual concerns, styles and philosophies of the various writers are so diverse, none includes Carmen de Burgos.

\footnotetext{
$\$ \quad$ Michael Ugarte. Madrid 1900: The Capital as Cradle of Literature and Culture (University Park: Pennsylvania State UP. 1996) 84.

" Roberta Johnson. "Carmen de Burgos and Spanish Modernism." South Central Review' 18.1-2 (2001): 66-67.

10) Johnson, 75 .

11 Sylvia Truxa. "Corrientes y prácticas literarias en la obra de Carmen de Burgos." Literatura y. pensamiento en España: Estudios en honor de Ciriaco Morón Arroỵo. Ed. Francisco la Rubia-Prado (Newark, DE: Juan de la Cuesta. 2003) 245-50.

12 Michael Ugarte, "Carmen de Burgos ("Colombine"): Feminist Avant la Lettre," Spanish women Writers and the Essay: Gender. Poetics and the Self. Eds. and Intro. Kathleen M. Glenn and Mercedes Mazquiarán de Rodríguez (Columbia: U of Missouri Press. 1998) 56.
} 
Along with several other women writers (among others Margarita Nelken, Concepción Arenal, and Isabel de Palencia), all inspired by $19^{\text {th }}$ century Krausism's emphasis on reason and justice, women's movements in other countries and the seminal work of Emilia Pardo Bazán, Carmen de Burgos was involved in efforts to forefront issues of inequality and injustice and wrote as a journalist, essayist, novelist and short-story writer and was not af raid to broach such subjects as divorce and abuse of women. Concepción Nuñez Rey notes that:

Carmen de Burgos fue una escritora de inmensa cultura, a la que guió siempre un anhelo de modernidad y de justicia social...representaba fielmente las corrientes de pensamiento libre y modernizador de las primeras décadas del siglo xx, las que fueron abolidas tras la guerra civil. Ella misma, con toda su obra, aparece entre los primeros autores prohibidos por decreto en los momentos iniciales de la posguerra.... ${ }^{13}$

And Maryellen Bieder in a recent study has written: "The contradictions and ambivalence that characterize Burgos's plotting of women and gender issues infuse all her writings and reflect the unresolved tensions in early-twentieth-century Spanish society." 14

Burgos's life reads like one of her works of fiction. She was born in 1867 in Rodalquilar, Almería (Andalucía), and married at age 16 an alcoholic, unfaithful husband. She did the work in his printing business because he neglected it, and she then obtained her elementary teaching certificate. After the death of her infant son, she left her husband and moved with her daughter to Madrid where she earned her living by writing articles for various newspapers. There she became the first woman to be part of the editorial staff of a newspaper, editing the daily

\footnotetext{
1.3 Concepción Nuñez Rey. Carmen de Burgos 'Colombine' en la edad de plata de la literatura española (Sevilla: Fundación José Manuel Lara. 2005) 10.

14 Maryellen Bieder. "Carmen de Burgos: Modern Spanish Woman," Recovering Spain's Feminist Tradition. Ed. Lisa Vollendorf (New York: MLA. 2001) 257.
} 
column "Lecturas para la mujer" in 1903 for the Diario Universal. Her husband died in 1906, and in 1908 she published her first collection of short stories, Cuentos de Colombine, and moved in with the writer Ramón Gómez de la Serna (21 years her junior) with whom she lived for some 20 years until he had a brief affair with her own troubled daughter. In 1909, she became the first Spanish woman war correspondent when she went to Morocco to cover the conflict there for El Heraldo de Madrid. Gabriela Pozzi tells how as a woman, she was sent to report on the "domestic" issues of the war, the human and personal side; she wrote of the soldier's lives, the stories of the wounded, and the horrors of combat. ${ }^{15}$ Much of her fictional work, as well as much of the work of her contemporaries, was published in popular Madrid weekly magazines such as La Novela Semanal and $E l$ Cuento Semanal. Her total production is astounding, including a dozen novel length works, 110 short novels or stories, 30 major translations into Spanish of works of such major figures as Tolstoy and Leopardi, literary studies of many Spanish works such as Amadis de Gaula and the stories of María de Zayas, several biographies, studies of contemporary issues such as women's rights, and hundreds of newspaper articles, including hints for homemakers and beauty tips as well as her more serious journalism. She died in 1932.

Many of her short novels and stories can be used as illustrative of ways for literature to depict culture and its often conflictive and selfcontradictory elements. It is particularly useful to study a neglected author from the margins of a major literary epoch to depict how skewed our vision of culture can be when such readings are omitted. Were students only to be presented with works by canonical Generation of ' 98 authors, they would think that the woman question was hardly an issue in turn-of-the century Spanish society. Through reading and analysis of authors such as Carmen de Burgos, students can appreciate

15 Gabriela Pozzi. "Carmen de Burgos and the War in Morocco." MLN. Hispanic Issue. 115 (2000): 188. 
the struggles women of the time faced, the ambiguities of their positions, the legal hurdles to be overcome, and the sheer nerve it took a woman author to confront societal injustice. They also get slices of life during that period as viewed through the lens of a woman's eye.

One of Carmen de Burgos' early stories from her collection Cuentos de Colombine, "Por las animas," is a concise and captivating image of what can be regarded as culture through literature. The male protagonist of the story is the emotionally distraught, irrational, and "hysterical" partner in the marriage. Narrated from his point of view of the marital situation in a rather melodramatic way, Burgos actually highlights the rationality of the female position. Anja Louis has written of the melodramatic tendencies in Burgos's fiction; and following Peter Brooks arguments about the origins and use of melodrama to express subversive ideas, she notes that: "In adapting the radical potential of melodrama to a feminist agenda, Burgos subverts melodrama and is acting in consonance with feminist demands of the time, namely that civil rights extended to male citizens...should also be extended to women." 16

The story opens by providing a wonderful vignette of an awakening Madrid. Burgos situates the reader in the Mediodía (now Atocha) train station with mention of the surrounding buildings and other landmarks in Madrid, the activities of a mobile café serving up typical breakfast food, the sweepers and other workers arriving early, the trains starting up with their various strident noises, and descriptions of the effects of the dawning light on it all. Without discussing cultural objects, and before the telling of the "story" has begun, students get a feel for the location and the food, clothing, transport and work accoutrements of turn-of-the-century Madrid. Then the character Manuel, disheveled and confused, is introduced to the reader by his friend, Álvaro, who finds him by an entrance to the train station. From

16 Anja Louis, "Whose Melodrama is it Anyway? Women and the Law in the Work of Carmen de Burgos," Bulletin of Hispanic Studies 81.6 (2004): 770. 
the fact that Álvaro says he has nothing pressing to do, and immediately invites Manuel to board a streetcar and go to a café, we can infer that neither man has to work for a living. More evidence of the class to which they belong is revealed in their conversation that follows (descriptions of wife and mistress and their clothing for example). Manuel then reveals to Álvaro the source of his torment. He has a mistress and feels that this only enhances his marriage. He loves and adores his wife, but also needs the excitement of his mistress:

No me creía culpable por tener estos amores; era un rato empleado agradablemente, que en nada perjudicaba a mi esposa... Al contrario, redoblaba mis atenciones para con ella. La infidelidad del marido es siempre provechosa para la mujer, con tal de que ella no lo sepa. ${ }^{17}$

However, one Sunday he finds out that his mistress gives money to the Church for the souls in purgatory, and that her Jesuit confessor then forgives her for her sin of having a lover. He arrives home to find that his wife is at a Jesuit church; and when she returns and casually mentions that she gives money to the Church for the blessed souls in purgatory, Manuel jumps to the conclusion that she also does so to be forgiven for having a lover. He reacts violently:

Ciego, loco, como si fuera cierta la visión que la imaginación me fingía, rechacé a Amparo con brutalidad, arrojándola contra el ángulo del sofá.

— ¡Infame! ¡Infame! —exclamé apretándole los brazos loco de furor- ¡Tú también... manos. ${ }^{18}$

...La hubiera matado a no entrar los criados y quitarla de mis

\footnotetext{
17 Carmen de Burgos, "Por las ánimas." Cuentos de Colombine. (Valencia: Sempere. 1908) 28.

is Burgos, "Por las ánimas," 36.
} 
He cannot forgive her for what he conceives to be her unpardonable sin, even though she either is or feigns to be totally confused about what he is implying. He tells his friend that his marriage is over because he can no longer ever trust his wife. Without mentioning the "double-standard," the story has illustrated the male point of view, and without mentioning a possible female opposing view, has shown how irrational the accepted cultural mores are. Along the way students have been treated to one view of life in Madrid and have been introduced to common cultural practices of the time such as giving money for prayers for the souls in purgatory. They have inferred from the story that it was common for an upper-class man to have a mistress, but that the opposite was not socially acceptable. Burgos carried this idea even further in her short novel "El Artíclo 438 ," the title naming the law that literally allowed a man to get away with murder if the murder were of his wife or her lover caught in an adulterous act. Ugarte in his analysis of another of Burgos's novels, $L a$ rampa. states that for Burgos: "... the moral, clinical, or scientific ills of Madrid have to do primarily... with the victimization of women." 19 And while La rampa is about two working class young women in Madrid. his statement that "...Burgos is openly sympathetic and complicitous in the "crime" of having been born a woman" 20 could as well be applied to the above short story of the condemnation of an upper-class wife and the destruction of her marriage because of traditional cultural assumptions.

Whereas "Por las ánimas" deals with the concerns of a woman in upper-class urban society, and adopts a critical, consciousnessraising point of view, the short story "Madre por hija" reflects working-class rural life; and while illustrating how difficult life is for a woman who is coerced into submitting to the will of a man, concludes less pessimistically. This may well reflect a bias of the author, who

19 Ugarte, Madrid 1900. 100.

20) Ugarte, Madrid 1900. 102. 
spent her childhood and youth in rural Andalucia, and had the tendency to idealize the setting throughout her work. ${ }^{21}$ However, right from the beginning of "Madre por hija" the narrator makes a comment in opposition to societal norms. The widow María: “...sufría la pobreza orgánica de las hembras sujetas a la inmoralidad de la monogamía. Todos los años tenía un chiquillo y se le moría otro" [emphasis mine]. ${ }^{22}$ María did not suffer abuse during her marriage, and if she didn't love her husband, had grown accustomed to him. As the story begins, she operates theirgrain mill after his death. Of her two surviving children, one son is married and lives a few miles away; the other is grown but lives with her. As she is closing up the mill one night an armed neighbor, José Manteca, demands entrance and searches the house and mill for María's son, Frasquito, who he claims has stolen his daughter from him. She tries to calm him, insisting that his daughter and her son can simply marry. But according to the narrator, José is not as concerned about his daughter as he is about himself:

No era el casamiento de la hija lo que le producía inquietud. Acostumbrados estaban allí a que los enamorados se juntaron, sin escándalo de nadie y sin darles de comer a los curas para que los bendijesen. Era la falta de la mujer en la casa, la necesidad de verla a su lado, de no estar solo. lo que le enfurecía; por eso se había opuesto al noviazgo y por eso mataría al que le había quitado a su hija. ${ }^{23}$

Further evidence of his macho behavior ensues as María, terrified for the life of her son, follows a determined José as he marches off the several miles to María's other son's house in search of Frasquito.

\footnotetext{
21 Concepción Nuñez Rey. "Introducción," La Flor de la Playa y otras novelas cortas. Carmen de Burgos Colombine. (Madrid: Castalia, 1989) 11.

22 Burgos, "Madre por hija," Cuentos de Colombine. Valencia: Sempere. 1908, 39-40.

23 Burgos. "Madre por hija." 43.
} 
Y seguía José su carrera, con la vara en la mano y las armas en la faja, sin hacer caso de la pobre mujer que, tropezando con las piedras y las cintas de sus alpargatas, le seguía siempre cayendo y levantándose, mientras murmuraba con voz suplicante:

— ¡José, José; por caridad, no mates a mi hijo! ${ }^{24}$

As they continue together, the countryside is narrated in idyllic tones: "brillaba la luna," "[u]n panorama de ensueño," "[d]ormía el pueblecillo a los pies del cerro," "la dulce música misteriosa del campo," 25 and the two are finding a certain charm in each other: "[e]ra buen mozo...y hasta lo había encontrado simpático," and "sentía subirse a la cabeza un perfume femenino."26 Finally José halts and suggests: "Yo perdonaría a tu hijo si tú vinieras conmigo. Hace falta una mujer en mi casa. El molino para los muchachos; tú para mí... ¡Cambio hija por madre!"27 She at first demurs but soon resigns herself to the situation: "Suspiró María un beso de sumisión como hembra resignada a la doble cadena de la fuerza del macho y de sus propios deseos." 28

In this short story there are some descriptions of cultural objects such as the mill and clothing. Cultural practices in the country such as commonly living together without marriage are mentioned. Vocabulary different from a more urban usage is encountered as in the use of hembra and macho for people as well as animals. The message here is more muted than in "Por las ánimas;" María submits to José's suggestion mostly to save her son's life, but also because she is softened and seduced by the music of the countryside, the moonlight, and José's physique. According to the narrator, the result is still that José needed a woman around the house and will let his daughter go

\footnotetext{
Burgos. "Madre por hija." 45.

Burgos, "Madre por hija," 44-45.

Burgos, "Madre por hija." 45

Burgos, "Madre por hija." 46-47.

Burgos, "Madre por hija," 47.
} 
because he has secured a replacement, but the ending has a somewhat subdued, not unpleasant tone to it. Maryellen Bieder notes the "contradictions and ambivalence" about gender issues in Burgos's work that "reflect unresolved tensions in early-twentieth-century Spanish society" and that may be due to her necessity of appealing to a more conservative public. ${ }^{29}$ So in "Madre por hija," María willingly gives herself to José, and even in "Por las ánimas," though the message of the injustice of the double standard is strong, yet the reader does not know if Manuel's wife did have a lover or was falsely accused.

Taken together, these two stories depict slices of life from Spanish urban and rural society in the early years of the $20^{\text {th }}$ century seen through a female perspective that of fers some challenges to the norm. Bieder writes of Burgos's fiction that it often features a woman at a defining moment in her relations with men. ${ }^{30}$ Both "Por las ánimas" and "Madre por hija" take place at just such a moment, and both include messages that the author, a marginal figure in the literary world, intended her audience to receive about the position of woman and her lack of power. These messages were not being sent by the mainstream literary figures of her age, but provide a bit of "social modernism" or intrahistoria to round out the picture of a generation. Teaching her short stories as conveyers of cultural patterns often omitted from discussions of this era in Spain can be a rewarding exercise in bringing to life the lives and concerns of that "silent and absent" half of Spanish society. They also bring into the classroom what Swaffer calls "demanding" literature: works that challenge cultural norms ${ }^{31}$ as Burgos's work certainly does. Students of such literature have an opportunity to examine not only literature which presents an oppositional and of ten omitted perspective, but also how such literature may have affected readers of that time.

\footnotetext{
$29 \quad$ Bieder, 257.

30 Bieder, 252.

3) Swaffer, 245.
} 
Wolfgang Iser (quoted in Jean Marie Schultz) once wrote: "The meaning of a literary text is not a definable entity, but... a dynamic happening which allows us to experience things that no longer exist and to understand things that are totally unfamiliar to us. ${ }^{~} 32$ Literature thus provides us with an ideal medium for the experiencing of a particular culture at a certain moment, including its contradictions and ambiguities.

$32 \quad$ Schultz. 9. 